\title{
Cooperative Learning in English Class of Chinese Junior High School
}

\author{
Ping Wei1, Yu Tang² \\ ${ }^{1}$ School of Foreign Languages, Southwest University, Chongqing, China \\ ${ }^{2}$ School of Culture and Social Development Studies, Southwest University, Chongqing, China \\ Email: weiping@swu.edu.cn, ty69@swu.edu.cn
}

Received 28 February 2015; accepted 16 March 2015; published 19 March 2015

Copyright (C) 2015 by authors and Scientific Research Publishing Inc.

This work is licensed under the Creative Commons Attribution International License (CC BY). http://creativecommons.org/licenses/by/4.0/

(c) (i) Open Access

\begin{abstract}
Cooperative learning has been widely used as a teaching method in English class around the world, which has attracted worldwide attention for its remarkable achievement. Since the introducing of cooperative learning theory to China in the late 1980s, thorough studies have been done by an increasing number of experts, scholars and front-line teachers of education. However, traditional English teaching which solely depends on teachers' imparting and focuses on standard instead of difference still plays a great role in English class in China now. This study is about using cooperative learning method in English class of junior high school, which includes theory analysis and experiment. The research has the following findings: Compared with the traditional ways, the implementation of cooperative learning method can, in fact, improve students' English academic achievement. Not only can it allow students to have more opportunities to learn actively and passionately, cooperate and communicate with others but also develop students' ability to integrate what they have learnt to use in real situation during the learning procedure. At the same time, the author summarizes and analyzes the advantages and disadvantages of cooperative learning and tries best to give suggestions for improvement, hoping that this can give some suggestions for the implementation of cooperative learning method in English class of junior high school.
\end{abstract}

\section{Keywords}

Cooperative Learning, English Teaching, English of Junior High School, Group Learning

\section{Introduction}

Science and technology developments in China have changed the old model of traditional education whose purpose is imparting knowledge only. The International 21st Century Education Committee has reported to UNESCO which points out four pillars of education, and "learning to cooperate" becomes one of them. 


\subsection{Definitions of Cooperative Learning}

The cooperative learning theory founders of the United States, David Johnson and Roger Johnson, thought that in the ideal classroom of cooperative learning, all students would learn how to work cooperatively with others, compete for fun and enjoyment, and work autonomously on their own (Johnson \& Johnson, 1984). In 1990, a famous American researcher, Robert Slavin, from Johns Hopkins University, regarded cooperative learning as a "teaching pattern" in which students learn in groups and are evaluated by the performance of the whole group (Slavin, 1990). To the year of 2002, Wang Tan, a well-known Chinese researcher in cooperative learning, referred to some theories of Ellis and Kagan (1992) to describe that "cooperative learning was a basic style of heterogeneous learning group, used to promote students' learning achievement and group results based on the evaluation criteria and achieved teaching objectives for common teaching activities” (Wang, 2002: p. 32). His definition shows that cooperative learning promotes students' learning achievement in contrast with the traditional method in which students are generally concerned with improving their own individualistic rather than group-wide goals.

\subsection{Significance and Aims of the Study}

Vermette, an American scholar, regarded cooperative learning as the most important and successful model in recent decades of education reform (Vermette, 1998). At present, cooperative learning has also become a necessity in the new round of basic education reform in China. Therefore, to fully understand what cooperative learning means and how to use it to achieve its largest effect, the author has done this study. Johnson, one of the representatives of cooperative learning (Johnson \& Johnson, 2001), stated that in the classroom, the relationship among students is much stronger and more powerful than any other factors impacting on students' learning achievement. However, the importance of peer interaction in classroom is often ignored. So the author hopes that this study can do something to change the situation.

\section{Literature Review}

As an ancient concept of education and practice, cooperative learning has a long history.

In the first century, Quintillion of Ancient Rome argued that students could benefit a lot from learning from each other. In the late 1700s, British pastors, Joseph Lancaster and Andrew Bell made extensive use of cooperative learning groups in England, and the idea was brought to America when a Lancastrian school was opened in New York City in 1806. Within the Common School Movement in the United States in the early 1800s, there was a strong emphasis on cooperative learning. In the last three decades of the 19th Century, Colonel Francis Parker, an American educator, developed the enthusiasm, idealism, practicality of cooperative learning (Parker, 1883). His fame and success rested on his power to create a classroom atmosphere that was truly cooperative and democratic. Following Parker, John Dewey promoted the use of cooperative learning groups as part of his famous project method in instruction. In the late 1930s, however, interpersonal competition began to be emphasized in schools. In the late 1960s, individualistic learning began to be used extensively. In the 1970s, cooperative learning was proposed by David Knoots, an American educator. It is not until the 1970s that the systematic science research on applying cooperative learning to class began. Dodge, a famous psychologist, proposed the theory of target structure about competition and cooperation which built an important theoretical foundation for the classroom cooperation and ultimately leaded to the rise of the modem cooperative learning research boom in the early 1970s (Dodge, 1973). In the 1980s, cooperative learning began to be used in schools once again.

\section{Method}

\subsection{Participants}

In order to get more precise data, the author collected the final test results of all classes and chose two classes, one as a controlled class and the other as an experimental class. There were 53 students, 25 girls and 28 boys, in Class One and 51 students, 24 girls and 27 boys, in Class Two, ageing from 14 to 15. The academic performance of the two classes was nearly the same. The experiment lasted for five months from February to July.

\subsection{Instruments}

The instruments included tests, questionnaires and interview. 
The tests, both pre-test and post-test, were final exams of each semester of the school year conducted by the whole school.

The pre-questionnaire (Appendix A) focused to find the current situation of students' English learning such as their purposes, interests, attitudes, suggestions and so on. The post-questionnaire (Appendix B) mainly dealt with three points: 1) The effect of cooperative learning groups; 2) The benefits students get from the cooperative learning in English class; 3) The problems about the application of cooperative learning in English class. The questions were closed questions and open questions.

The data of interview (Appendix C) was collected from the students in the experimental class for more information.

\subsection{Procedure}

Before the implementation of cooperative learning, the author had studied the theory of cooperative learning at home and abroad conscientiously. Then the author chose two classes, an experimental class and a controlled class, and divided the students in the experimental class into 8 groups, six students a group. The author trained the students how to carry out the cooperative learning method firstly. After that, the author strictly organized classroom teaching according to the characteristics and nature of the theory of cooperative learning and collected data. The data are from tests, questionnaires and interview. Based on the situation, the questions for the research are set as follows:

Question one: Can cooperative learning method improve students' academic achievements compared with the traditional English teaching?

Question two: What are the advantages and disadvantages of cooperative learning method?

The controlled class was taught by traditional teaching method by the same teacher.

\section{Results}

\section{Question one: Can cooperative learning method improve students' academic achievements compared with traditional English teaching?}

At the beginning of the experiment, the scores of pre-test were used to test the coherence between the experimental class and the controlled class, in order to find out whether there were any significant differences between these two classes to ensure accuracy of the experiment.

Table 1 compares the English scores of the experimental class and the controlled class on the pre-test.

At the end of the experiment, the post-test was conducted to show the progress students made and the differences between the experimental class and the controlled class, in order to find out whether there were any changes after the implementation of the experiment.

Table 2 compares the English scores of the experimental class and the controlled class on the post-test.

The pre-test shows that students in the experimental class and the controlled class were almost at the same English level, as the average score, the portion of students with scores above 125 and the portion of students with scores above 90 were with no significant difference while the post-test form shows that students in the experimental class have made greater progress compared with the controlled class.

As in the pre-test, the score of controlled class was nearly the same as the experimental class in almost all areas. But in the post-test, the lowest score, the average score, the portion of students with scores above 90 and the portion of students with scores above 125 of experimental class over-passed that of the controlled class by a great deal. And the average score of the experimental class is obviously higher than that of the controlled class by more than 7 scores. The portion of students with scores above 90 of the experimental class is higher than that of the controlled class by more than $18 \%$. The portion of students with scores above 125 of the experimental class is higher than that of the controlled class by more than $3 \%$. The lowest score of the experimental class is higher than that of the controlled class by 12 scores. It shows that students in experimental class have made much higher progress after the implementation of cooperative learning.

In the pre-test, there were 18 students from the experimental class failed the test while in the post-test there is only 7 of the students from the experimental class who failed the test and even the scores of the 7 students have improved a lot.

Therefore, cooperative learning method can certainly improve students' academic achievements compared with the traditional English teaching. 
Table 1. Pre-test (The final exam of the first term).

\begin{tabular}{|c|c|c|c|c|c|}
\hline Score & $\begin{array}{l}\text { The highest } \\
\text { score }\end{array}$ & $\begin{array}{c}\text { The lowest } \\
\text { score }\end{array}$ & $\begin{array}{l}\text { The average } \\
\text { score }\end{array}$ & $\begin{array}{l}\text { Portion of students with } \\
\text { scores above } 125\end{array}$ & $\begin{array}{l}\text { Portion of students with } \\
\text { scores above } 90\end{array}$ \\
\hline Controlled class & 140 & 63 & 102.61 & 17.65 & 66.67 \\
\hline Experimental class & 141 & 65 & 102.94 & 16.98 & 66.04 \\
\hline
\end{tabular}

Table 2. Post-test (The final exam of the second term).

\begin{tabular}{lccccc}
\hline Class & $\begin{array}{c}\text { The highest } \\
\text { score }\end{array}$ & $\begin{array}{c}\text { The lowest } \\
\text { score }\end{array}$ & $\begin{array}{c}\text { The average } \\
\text { score }\end{array}$ & $\begin{array}{c}\text { Portion of students with } \\
\text { scores above 125 }\end{array}$ & $\begin{array}{c}\text { Portion of students with } \\
\text { scores above } 90\end{array}$ \\
\hline Controlled class (34) & 142 & 62 & 102.18 & 19.61 & 68.63 \\
Experimental class (33) & 142 & 74 & 109.73 & 22.64 & 86.79 \\
\hline
\end{tabular}

\section{Question two: What are the advantages and disadvantages of cooperative learning method?}

The Advantages of Cooperative Learning Method

- Arousing Students’ Interest in Learning English

Robert (1995) emphasized that cooperative learning can increase students' interest in learning English and change their attitudes toward learning English, too.

According to the pre-questionnaire, from the result of question 1, only less than 4\% students learnt English out of interest, about $74 \%$ of the students said that they learnt English for entering a higher school and nearly $22 \%$ of the students for their parents or teachers. When answering question 2 and 3, nearly 66\% of the students said they did not like English to some extent and less than $16 \%$ of the students said they liked English very much. So, most of the students were not so interested in English. As for the results of question 6 and 9, about 87\% of the students were not so interested in English class.

However, after implementation of cooperative learning method, the situation has changed to a large extent. Nearly 89\% students said that their interest in learning English and participating in English class was improved as shown in question 8 in the post-test. And in the interview, $80 \%$ of the students believed that cooperative learning stimulated their enthusiasm for English learning and participating in English class, 8\% of the students were not sure whether cooperative learning could stimulate their enthusiasm completely, the rest $12 \%$ of the students thought that cooperative learning had nothing to do with their enthusiasm for English.

- Involving Students in Cooperating and Learning

Based on the students' psychological characteristics, Luo Chaomeng (2001) stated that students will help others just because they care about them and want them to succeed. Group members cooperate and interact with kindness and they become friends during the process.

According to the post-questionnaire, from the result of question 3, nearly $72 \%$ of the students said that most of the questions in the class can be answered by discussing with other group members, and only $13 \%$ disagreed. From the result of question 6 , nearly $90 \%$ of the students said that cooperative learning had encouraged their cooperation with each other and help for each other during the implementation of the cooperative learning method, $6 \%$ were not so sure and only $4 \%$ disagreed. From the interview, 59\% of the students wanted to have interaction with the others after class. 33\% would interact with others under some specified conditions. Only $8 \%$ of the students did not want to share their achievement with other students. $81 \%$ of the students completely agreed that they can interact with the students to get more useful information. And the rest students partly agreed with that point. Cooperative learning made students depend on each other actively to achieve their common goal, share various source and praise.

- Fostering Students' Confidence

Most of the students believed that cooperative learning had created a more relaxed and harmonious atmosphere for them to learn which made them express themselves freely. He Gaoda (2002) thought that cooperative learning can foster students' confidence. Cooperative learning provided pair work and group work for students which helped students reduce their anxiety and made students confident during learning.

According to the pre-questionnaire, from the result of question 4, only less than $13 \%$ students English is easy and more than $87 \%$ of the students said that English is difficult to some extent. So, most of the students thought that English was difficult and they were not capable for it. As shown from question 5 in the post-questionnaire, 
more than $75 \%$ of the students agreed that the implementation of the cooperative learning method helped to improve their confidence in learning English, $14 \%$ of the students were not so sure and only $11 \%$ of the students disagreed. When answering question 4 in the post-questionnaire, nearly $81 \%$ of the students agreed that the implementation of the cooperative learning method helped to make them brave enough to express themselves to their classmates and teachers, $16 \%$ of the students were not so sure and only about $3 \%$ of the students disagreed. Some students said that they were more confident to communicate with others and express their own ideas as shown in the interview. From the interview, $89 \%$ of the students believed that they can learn much better and faster in cooperative learning than before while 7\% of the students felt they cannot.

\section{The Disadvantages of Cooperative Learning Method}

Cooperative learning truly bears many merits but its drawbacks cannot be overlooked. Its disadvantages are as follows.

- Diffusing the Responsibility

Some students do not want to or cannot do the things which they are distributed to do but depend on others. Or the class often tends to be dominated by a few outstanding students and many other students only seem to be their audience, sitting alone with nothing much to do. So they have fewer things to do in cooperative learning group. According to question 9 in the post-questionnaire, nearly $29 \%$ of the students said that other students can finish the tasks for the group and they were much easier after the implementation of the cooperative learning method. The result of question 10 shows that more than $20 \%$ of the students took the time for cooperative learning activities to chat freely with other students. It takes place when the cooperative learning group just needs to hand in a report or a paper. It will make some students with worse academic achievement be neglected. This is what Jaeobs called diffusion of responsibility (Jaeobs, Power, \& Inn, 2002). From question 15 in the postquestionnaire and the interview, many students stated that the tasks every student should finish must be fixed before implementing cooperative learning activities in order to avoid that some students were overburdened while others were bored.

- Having Vague Objectives

Cooperative learning sometimes has vague objectives and poor expectations for accountability, especially when the teacher and students involved lack necessary experience of cooperative learning. According to question 12 in the post-questionnaire, about $54 \%$ of the students said that some cooperative learning activities had vague objectives. This made students at a loss in class because sometimes they did not know clearly the goal that the group wanted to achieve and even what they were talking about. It really wasted time to figure out the objectives of their group work. From the interview, about $85 \%$ of the students suggested that clear instructions and goals for the group and every individual were essential to successful cooperative learning. They hoped that the teacher can repeat the objectives clearly based on the activities which had clear objectives. Then the teacher should go around the classroom to monitor what was happening and give instructions as well as helps if needed. The group leader was also expected to tell the objectives clearly and repeatedly to his members.

- Lacking Time for Learning Individually

More and more people have noticed that cooperative learning is very important in English class. An increasing number of teachers think that the class should be filled with cooperative learning activities as much as possible. As a consequence, the 45 minutes was taken up by teacher's explanation, students' cooperative learning activities and their presentation. At the same time, the time for students to learn individually and think about things all by themselves is shortened. According to question 11 in the post-questionnaire, nearly $71 \%$ of the students said that cooperative learning had made the time for learning individually not enough, $24 \%$ of the students said that they just had a little time for learning individually and only $5 \%$ of the students said that they disagreed. And from the interview, many students said that sometimes they had little time for learning individually, organizing and summarizing what they had learnt by themselves. In such a situation, they are worried about their future performance in English learning. So they desperately hoped that much more time for their own learning purpose was given.

\section{Discussion}

According to the research, we find:

First, in order to approach the challenges, the teacher has to prepare as much as possible. Before the implementation of cooperative learning, the teacher has to study the theory and practice of cooperative learning in 
class from home and abroad consciously, strictly organize classroom teaching according to the characteristics and nature of the theory of cooperative learning to make the experiment have a high theoretical starting point which can help to avoid it being just an experience and a form which definitely helps to achieve the final success. And also the special factors of Chinese students learning English have to be taken into account. However, no matter how hard the teacher has tried, he cannot be an expert of it. So there is still a lot needed to be improved constantly.

Second, it is a very important part of the experiment in cooperative learning to persuade them to accept this teaching mode and coordinate carefully in heart. It is of the same importance to train the students how to carry out cooperative learning method and define clearly the responsibilities of each member. Only if the teacher let the students understand the importance of implementing cooperative learning and stimulate the students' strong sense of participation can he ensure the smooth implementation of the experiment. And the teacher can also ask the group leader or the inspector to do a lot about this before and during the implementation of cooperative learning.

Third, it is necessary to create a favorable environment. If cooperative learning is used in class, the students will have more chances to talk with others and to share their ideas with others which will create the atmosphere of learning from the group members. Only in a favorable and safe atmosphere the teacher creates for the students can the students keep interest in learning. And when practicing using language, they will have no fear of or worry about the results, contribute themselves to cooperative learning activities actively, and finally benefit from the process. However, this kind of atmosphere will mostly be created by teacher's organization in class, that is, teacher is the "guide" and students are "tourists", but the focus of guidance is to arouse students' active and creative consciousness in learning.

Fourth, Sheng Qunli (1992) emphasized that when designing an activity, teacher should pay attention to that different parts of the text need different ways to deal with, even in the same passage. Apart from that, teacher also should take notice: the activity really happens in daily life and is operational; it should base on students' experiences and interest, contribute to students' improvement in abilities, skills and knowledge; the activity should accelerate the connection among subjects and then develop students roundly.

Fifth, it is important to build a suitable way of assessment for cooperative learning. During the whole evaluation, students' self-evaluation, the comments from other group members and the teacher's marks should be combined perfectly so that the students can take part in the entire course, which promotes the students to help each other and contributes to the cooperation. Evaluation aims at the cooperation in each group and competitions among groups. Therefore, any progress each student makes in cooperative learning belongs to the whole group. What's more, students should be evaluated in many aspects during the implementation of cooperative learning. The way of self-evaluation and mutual evaluation creates a much fair and more scientific atmosphere. Apart from that, the teacher needs to evaluate every student, too.

\section{Conclusion}

The development of cooperative learning is quite fast and increasing attention has been paid to it. This study is about using cooperative learning method in English class of junior high school, which includes theory analysis and experiment.

During the learning and implementation of cooperative learning method, the author finds that cooperative learning method can certainly improve students' academic achievements compared with the traditional English teaching. What's more, cooperative learning can increase students' interest in learning English and English class and change their attitudes toward learning English and English class, foster students' sense of responsibility, confidence, friendship, cooperation and concentration and help to build a learner-centered atmosphere in the classroom. Students in such classroom will feel free and easy to show their performance, either to interact or to learn. And also, they will not be afraid of speaking to others or sharing their ideas with others any longer. Thus, once the learning tasks are designed to be completed in the small team, their anxiety to make mistakes will be certainly reduced.

Certainly, as we all know, there is not a suitable almighty mode or means in any teaching. Cooperative learning is no exception. There are still some defects for cooperative learning itself. For example, the evaluation in cooperative learning has not been attached enough importance to. Some cooperative learning activities are not so reasonable, etc. What the author has done is just trying to learn more about cooperative learning and to put it 
into practice, hoping this can improve our understanding and implementation of it.

In fact, the survey is a relatively small one and because of the time limitation, the sample in this study was a small one. Deeper study with larger sample is needed to testify the validity of the experiment.

\section{Funding}

The paper is supported by "the Fundamental Research Funds for the Central Universities” (No.: SWU1409317) and "the Specially Commissioned Research Funds of the Chongqing Federation of Social Science Circles" (No.: 2014TBWT02-2).

\section{References}

Dodge, K. A. (1973). The Target Structure about Competition and Cooperation. Journal of Educational Psychology, 69, 121128.

He, G. D. (2002). Research on Learning Foreign Language Cooperatively under Modern Educational Technology Environment. Foreign Languages Teaching, 6, 76-81.

Jaeobs, G. M., Power, M. A., \& Inn, L. W. (2002). The Teacher's Sourcebook for Cooperative Learning: Practical Techniques, Basic Principles, and Frequently Asked Questions. Thousand Oaks, CA: Corwin Press.

Johnson, D. W., \& Johnson, R. T. (1984). Cooperation and Competition: Theory and Research. Edina: Interaction Book Company.

Johnson, D. W., \& Johnson, R. T. (2001). Learning Together and Alone. Upper Saddle River, NJ: Prentice Hall.

Luo, C. M. (2001). Basic Concept of Cooperative Teaching and Its Application in SEFC Teaching, Primary English Teaching and Research, 4, 78-83.

Parker, F. W. (1883). Talks on Teaching. New York: Praeger Publisher.

Robert, E. S. (1995). Research on Cooperative Learning and Achievement: What We Have Known or What We Need to Know. Belmont, CA: Wadsworth Publishing Company.

Sheng, Q. L. (1992). A Review on the Innovation of Cooperative Learning. Materials of Foreign Education, 3, $24-32$.

Slavin, R. E. (1990). Synthesis of Research on Cooperative Learning: Educational Leadership. Oxford: Oxford University Press.

Vermette, P. J. (1998). Making Cooperative Learning Work: Student Teams in K-12 Classrooms. Englewood Cliff, NJ: Prentice-Hall, Inc.

Wang, T. (2002). A Brief Discussion on the Cooperative Learning. China Journal of Education, 1, 32-35. 


\section{Appendix A: Pre-Questionnaire}

1) The reasons why you study English:
A. own interests
B. Parents or Teachers force me
C. For future study
D. other reasons
2) Do you like English?
A. Like it very much. B. Like it a little.
C. Hate it a little.
D. Hate it very much.
3) Your attitudes towards English is:
A. Positive
B. A little positive
C. A little negative
D. Negative
4) You think English is:
A. very difficult
B. a little difficult
C. a little easy
D. very easy

5) Usually you finish English homework:
A. independently
C. copy others' occasionally
B. with the help of teachers or classmates
D. always copy others'

6) Your attitudes towards English class is:
A. very interested
B. a little interested
C. sometimes interested, sometimes not
D. not interested

7) Your suggestion to English class is
A. teacher lectures more, students practice less
B. teacher lectures less, students practice more
C. teacher lectures a half, students practice a half
D. students practice mainly, teacher coaches

8) You hope in English class:
A. teacher controls everything
B. students have the freedom to do everything
C. Students just need to listen, need not be involved
D. The classroom is lively and vivid, teacher and students interact with each other

9) Are you interested in you English class now? If no, give your reasons.

10) Are you satisfied with the teaching way your teacher uses now? If no, give your reasons and suggestions.

\section{Appendix B: Post-Questionnaire}

1) Do you participate in group cooperative learning actively?

2) Can Your group finish the assignment within the specified time?

A. Yes B. No C. Uncertain

3) Can many problems in class be solved in group cooperative learning?

A. Yes

B. No C. Uncertain

4) Are you more willing to express your opinions in group cooperative learning?
A. Yes
B. No
C. Uncertain

5) Do you improve your self-confidence in group cooperative learning?

A. Yes B. No C. Uncertain

6) Do you learn how to cooperate with others in group cooperative learning? A. Yes B. No C. Uncertain

7) Do you improve your study in group cooperative learning? $\quad$ A. Yes $\quad$ B. No C. Uncertain

8) Do you improve your interest in English in group cooperative learning? A. Yes B. No C. Uncertain

9) Do you feel more leisurely because others can finish the tasks in group cooperative learning?

A. Yes B. No C. Uncertain

10) Do you think the time spent in group cooperative learning is the time you can chat with others?
$\begin{array}{lll}\text { A. Yes } & \text { B. No } & \text { C. Uncertain }\end{array}$

11) Do you think group cooperative learning waste your own study time? A. Yes B. No C. Uncertain

12) Do you think the goals set in group cooperative learning are not definite? A. Yes B. No C. Uncertain

13) Do you think the evaluation ways in group cooperative learning is not reasonable?
A. Yes
B. No
C. Uncertain

14) Which is better, the traditional teaching way or the group cooperative learning? Why?

15) Do you have any suggestions for the group cooperative learning?

\section{Appendix C: Interview}

1) Can you tell me your idea after implementing cooperative learning in this semester, including good points, bad points and improvement in the future?

2) Do you think what the teachers should do in implementing cooperative learning? 